\title{
Digitizing the grey areas in the Nigerian public procurement system using e-Procurement technologies
}

\section{Adedeji Afolabi, Eziyi Ibem, Egidario Aduwo \& Patience Tunji-Olayeni}

To cite this article: Adedeji Afolabi, Eziyi Ibem, Egidario Aduwo \& Patience Tunji-Olayeni (2020): Digitizing the grey areas in the Nigerian public procurement system using eProcurement technologies, International Journal of Construction Management, DOI: 10.1080/15623599.2020.1774836

To link to this article: https://doi.org/10.1080/15623599.2020.1774836

Published online: 08 Jun 2020.

Submit your article to this journal $₫$

Q View related articles $\asymp$

View Crossmark data 